Agro-Science Journal of Tropical Agriculture, Food, Environment and Extension Volume 17 Number 2 (Mav 2018) pp. $51-57$

ISSN 1119-7455

\title{
EFFECT OF ACCESS TO MICROCREDIT ON PRODUCTIVITY AND PROFITABILITY OF CASSAVA FARMING IN OSUN STATE, NIGERIA
}

\author{
Ogunleye A.S. \\ Department of Agricultural Economics, Faculty of Agriculture, \\ Obafemi Awolowo University, Nigeria
}

Email:ogunleyedeji@yahoo.co.uk; ogunleyedeji@yahoo.co.uk; ogunleyedeji@oauife.edu.ng

\begin{abstract}
The study examined the effect of access to microcredit on the productivity and profitability of cassava production. A multi-stage sampling procedure was used to obtain the data from 100 respondents. Primary data collected were analyzed using descriptive statistics, budgetary analysis and stochastic production frontier. Result showed that cassava farming in the study area was dominated by male farmers with about $81.3 \%$ and82.7\% for microcredit users, and non-microcredit users, respectively. It also revealed that few farmers (48\%) had access to credit. The farm budgetary analysis revealed that the net profit per hectare were $\$ 68,719$ for microcredit users and $\$ 68,298$ for non-microcredit users. The distribution of the technical efficiency according to accessibility to credit showed that the microcredit users were little more technically efficient $(T E=0.9638)$ than the nonmicrocredit users (TE=0.9556). The result showed that labour, farm size, and fertilizer significantly influenced technical efficiency among users while farm size, fertilizer, gender and extension visits significantly influenced technical efficiency among non-microcredit users. The study concluded that cassava production was more profitable and efficient among cassava famers who had access to microcredit in the study area. The study recommended that cassava farmers should be encouraged with improved access to microcredit in order to boost their productivity and profit level in the study area.
\end{abstract}

Keywords: Microcredit, productivity, profitability and cassava production.

\section{INTRODUCTION}

Cassava (manihotspp) is an exceptional food and cash crop in different tropical countries in Africa, where it play a key role in the economy (Okoye et al., 2016). It is a good source of carbohydrate, vitamins and minerals (Nweke, 2004; Salvador et al., 2014). It could be processed into numerous forms such as garri, fufu, tapioca, cassava flour, chips, paper, pellets, adhesives and even used in pharmaceuticals companies (Salvador et al., 2014). Also, the peels are used in organo-mineral fertilizers formulation (Ojeniyi, 2001). The Federal Government of Nigeria has placed emphasis on the production of cassava in all its environs. This could be ascribed to its different uses for more than 60 million people in Nigeria (Abdulahi, 2003; Ndubueze and Ekine, 2014). According to Rahji and Fakayode, (2009), small scale farmers in Nigeria have been the major producers of cassava and they have been increasing their production over the past 50 years. This has led diversion to commercial production which is described as the cassava transformation (Nweke, 2004). In spite of their potential, the small scale farmers has consistently been faced with shortage of formal credit facilities which often prevent them from improving their productivity and net profit (Onu, 2003). Nwaru (2011) has described Agricultural credit as transferring of purchasing power from the owner to someone who is in need of it on a temporary basis with the willingness and ability to repay it back at a specified period with or without interest. This credit is in form of small loan giving to small scale farmers to help them engage in productive activity. However, studies (Odoemenem and Obinne, 2010; Ashaolu et al., 2011; Zahra and Gulcan 2016) has shown that farmers with access to credit adopted more technologies than those who did not. This implied that availability of credit facilitates technology adaptation which could further improve their socio-economic condition and productivity. In light of the above mentioned, this study investigated the productivity and profitability differentials among 
cassava farmers which had access to microcredit and those who did not have access to microcredit.

\section{MATERIALS AND METHODS \\ Study Area}

This study was carried out in Osun state, the state was carved out of the old Oyo state on the 27th August, 1991, by the then military administration. There are more than 200 towns, villages and other settlement in the state, which has a considerable number of highly urbanized settlements. The State is divided into three federal senatorial districts, namely, Osun East, Osun West and Osun Central. The state consists of 30 Local Government Area and one Area office (at Modakeke). The state has a total land area of about 9,250.92 square kilometers $(3,571.8$ squre miles) and a population of $3,416,059$ comprising of $1,734,149$ male and $1,682,810$ females, according to the 2006 population and housing census of the Federal Republic of Nigeria. It lies between latitude $703010 \mathrm{~N}$ and longitude $403010 \mathrm{E}$ with an altitude of 246 meters above the see level. The state is situated in the tropical rain forest with main seasons: the rainy season that runs between March and October, while the dry season occurs between November and February. The main rainfall ranges between $800 \mathrm{~mm}$ in the savanna agro ecology to $1500 \mathrm{~mm}$ in the rainforest belt. The annual mean temperature is about 200C. The state has a well drain loamy and clay soils which are very suitable for agriculture and one of the major crops being cultivated in the state is cassava.

\section{Sampling procedures and sample size}

A multi-stage sampling procedure was used to select the respondents. At the first stage two administrative zones were randomly selected and these were Ife and Iwo zone. The second stage involved random selection of one local government area (LGA) from each of the chosen administrative zone making a total of two LGAs. At the third stage a total of 10 communities were selected proportionately to sizes (depending on the number of the communities in each LGA) of the chosen LGAs. At the final stage, five cassava farmers were randomly selected from each community to make a total of 100 respondents. A well-structured and pre-tested questionnaire was used to elicit information from the respondents. The survey questionnaire captured information on the socioeconomic characteristics of the respondents, such as age, gender, household size, education, extension contact, credit access and farming experience. It also solicited information on technical factors such as labour, fertilizer, pesticides and farm size.
Information on cassava output was also captured using the survey questionnaire. The proportionality factor used in the selection of cassava farmers was defined as:

$$
\mathrm{Xi}=(\mathrm{n} / \mathrm{N})^{*} 10
$$

where $\mathrm{Xi}=$ number of cassava farmers to be sampled from a LGA, $n=$ number of registered cassava farmers in the particular LGA (list obtained from local agriculture extension officer), $\mathrm{N}=$ sum total number of cassava farmers in the two LGAs.

\section{Analytical techniques 1descriptive statistics}

Descriptive statistics (means, standard deviation, frequency count and percentages) was used to describe the socio-economic and demographic characteristics of the farmers in the study area using frequency counts, percentages, means and tables.

\section{Budgetary analysis}

Budgetary analysis was used to compare the level of profitability among the respondents. It was calculated using the formulas below:

\section{Net income model}

The net income model used was as expressed as below in equation (ii)

$$
\mathrm{NI}=(\mathrm{TR}-\mathrm{TVC})-\mathrm{TFC}
$$

Where NI $=$ Net income in Naira/ha, $\mathrm{TR}=$ Total Revenue in Naira/ha, TVC $=$ Total Variable Cost in Naira/ha, TR-TVC $=$ Gross Margin in Naira/ha, TFC $=$ Total Fixed Cost in Naira Cost function estimation model for cassava was expressed as in equation (iii) below

$$
\mathrm{TC}=\mathrm{TFC}+\mathrm{TV}
$$

where: TC - Total Cost in Naira/ha, TFC - Total Amount on Depreciation on Fixed Assets in Naira/ha, TVC - Total Variable Cost in Naira/ha

\section{Revenue and net profit estimation model}

The revenue model used was expressed as follows:

$$
\text { TR=TQx P }
$$

Where: $\mathrm{TR}=$ Total Revenue in Naira/ha, TQ Total output of cassava in $\mathrm{Kg}, \mathrm{P}$ - Price per $\mathrm{Kg}$ of cassava in Naira Net Profit model was expressed as in equation (v)

$$
\mathrm{TR}-\mathrm{TC}
$$


where: TR - Total Revenue in Naira/ha and TC Total Cost in Naira/ha.

\section{Technical efficiency (stochastic frontier} production function)

This analytical tool was used to determine the productivity and effect of access to microcredit on the productivity of the respondent. The CobDouglas frontiers production function which was defined as in equation (vi):

$\operatorname{In} Y i j=\beta o+\beta 1 \operatorname{In} X i j+\beta 2 \operatorname{InX} 2 i j+\beta 3 \operatorname{In} X 3 i j+\beta 4 \operatorname{In} X 4 i$ $\mathrm{j}+\beta 5 \operatorname{InX} 5 \mathrm{ij}+(\mathrm{Vij}-\mathrm{Uij})$

The subscripts $i$ and $j$ refer to the $j$ th farmers and jth observation respectively in all cases. Where: In - Natural logarithms, Y - Cassava outputs (kg/ha), X1 - Labour used (Man-days), X2 Farm size for cassava (ha), X3 - Quantity of fertilizer used $(\mathrm{kg} / \mathrm{ha}), \quad X 4$ - Members of association, X5 - Total cost ((naira ( $\mathrm{N} / \mathrm{ha}), \beta 1$ $\beta 5$ - coefficients of parameters to be estimated, $\beta 0$ - Technical efficiency level, Vij - Systematic random error that accounts for measurement error and other factors that are not under the control of the farm household and $\mathrm{Uij}$ Asymmetric non-negative random error component that measures technical inefficiency effects The inefficiency model estimates which was jointly used with the stochastic frontier model in order to determine the factors that contribute directly to technical efficiency in all the groups examined was stated in equation (vii) $\mathrm{Uij}=\alpha 0+\alpha 1 \mathrm{Z1}+\alpha 2 \mathrm{Z} 2+\alpha 3 \mathrm{Z3}+\alpha 4 \mathrm{Z} 4+\alpha 5 \mathrm{Z} 5$ (vii) where: Z1 - Farming experience (years), Z2 Household size (no), Z3 = Education (years), Z4 - Gender (male - 1, others - 0), Z5 - Extension visit (yes -1, No - 0), $\alpha 1-\alpha 5$ parameters to be estimated.

\section{RESULTS AND DISCUSSION}

Socio-economic characteristics of cassava farmers

The socioeconomic distributions of the cassava farmers showed that majority $(82.0 \%)$ of the respondents were male (Table 1). This implied that males were more committed to cassava production than their female counterparts. This result confirmed the findings of Yakasai, (2010) which reported that cassava production was a male dominated enterprise. The average age of the farmers in the study area was 50years. This implied that the farmers were in their active age. Majority $(88.0 \%)$ of the respondents were married with household size of between 6 to 8 members. It could be inferred that majority of the cassava farmers were expected to have some forms of financial commitment to their family members. This should influence their agricultural practices in terms of productivity and the level of profit. The results further showed that farmers in the study area have farm sizes of between 2 to 5 hectares. This implied that the cassava farmers in the study area were smallholders. The results also showed that majority $(83.0 \%)$ of farmers in the study area had some forms of education. Thus, they were expected to be able to interpret, understand and use available resources and technology to boost their level of cassava production. The average farming experience was 20years in the study area. This implied that the farmers have many years of farming experience; hence adopting modern farm practices among the farmers in the study area should not be difficult. Majority $(89.8 \%)$ of farmers also engaged in other farm enterprise through which they also generate additional income.

\section{Budgetary analysis result}

The result of the budgetary analysis was presented in Table 2 below. The result showed the level of profitability among the two groups of cassava farmers in the study area (microcredit users and non-microcredit users). The total variable cost per hectare which consists of cost of planting, weeding, fertilizer, thinning, harvesting, transport, and marketing were very high for cassava farmers with access to microcredit ( $131,177.00)$ compared to those without access to microcredit ( $\$ 88,437.00$ ). This difference could be traced to access to microcredit for the farmers.

Table 1. Socio-economic characteristics of cassava farmers

\begin{tabular}{llll}
\hline Variables & $\begin{array}{l}\text { Farmer with access to } \\
\text { microcredit }\end{array}$ & $\begin{array}{l}\text { Farmers without access to } \\
\text { microcredit }\end{array}$ & $\begin{array}{l}\text { All } \\
\text { samples }\end{array}$ \\
\hline Male (\%) & 81.3 & 89.6 & 82.0 \\
Age (years) & 50.0 & 50.0 & 50.0 \\
Married (\%) & 89.6 & 86.5 & 88.0 \\
Farm size (hectares) & 3.5 & 2.0 & 3.5 \\
Literacy level (\%) & 91.7 & 75.0 & 83.0 \\
Household size (nos) & 7.0 & 7.0 & 7.0 \\
Year of farming experience (years) & 20.0 & 20.0 & 20.0 \\
Engagement in other enterprises(\%) & 87.5 & 92.0 & 89.8 \\
\hline
\end{tabular}

Source: Field Survey, 2017 
Table 2: Estimated average cost and profitability of farmers that have access to microcredit and those without microcredit.

\begin{tabular}{llll}
\hline Variable & $\begin{array}{l}\text { Farmers with access to } \\
\text { microcredit (N/ha) }\end{array}$ & $\begin{array}{c}\text { Farmers without access to } \\
\text { microcredit(A/ha) }\end{array}$ & $\begin{array}{l}\text { All Samples } \\
\text { (A/ha) }\end{array}$ \\
\hline Total Revenue(TR) & $199,896.00$ & $156,735.00$ & $177,452.00$ \\
Variable cost & & & $23,525.00$ \\
Planting & $26,167.00$ & $21,087.00$ & $28,411.00$ \\
Weeding cost & $35,948.00$ & $21,454.00$ & $7,870.00$ \\
Fertilizer & $10,313.00$ & $5,615.00$ & $7,575.00$ \\
Thinning & $9,604.00$ & $5,702.00$ & $27,220.00$ \\
Harvesting cost & $32,854.00$ & $22,019.00$ & $8,085.00$ \\
Transport cost & $9,229.00$ & $7,029.00$ & $6,266.00$ \\
Marketing cost & $7,063.00$ & $5,531.00$ & $108,952.00$ \\
Total variable cost & $131,177.00$ & $88,437.00$ & $68,500.00$ \\
Gross Margin & $68,719.00$ & $68,298.00$ & $123,952.00$ \\
Total Cost & $146,177.00$ & $103,437.00$ & $53,500.00$ \\
Net Profit & $53,719.00$ & $53,298.00$ & \\
\hline Source: field & & &
\end{tabular}

Source: field survey, 2017

This implied that cassava farmers who had access to microcredit invested more on their cassava enterprise as compared to those without access to microcredit. This result confirmed the findings of Miguel (2007), Balogun et al. (2011) and Taiwo (2012) which all argued that access to microcredit strengthens the productive assets of the farmers by enabling the them to secure adequate investment capital which could be used to further invest in productivityenhancing technologies such as fertilizer, better tools, among others. The total revenue for the farmers with access to microcredit ( $1199,896.00)$ was higher than the farmers without access to microcredit (156, 735.00). This could be traced to the level of investment made on cassava enterprise by those who had access to microcredit as compared with those who did not have access to microcredit. This probably accounted for more output per unit area among those who had access to microcredit. The total cost for the microcredit group is higher $\$ 46,177.00$ and could not minimize cost as cassava is a low input- high yielding crop which does not require much variable input such as fertilizer before it produces effectively unlike other crops. This high variable cost among farmers which had access to microcredit helped to maximized the average gross margin ( $168,719.00)$ and the net profit ( $\$ 53,719.00)$ gotten from each production compared with those who did not have access to microcredit which had average gross margin ( $\$ 68,298.00)$ and net profit of $\$ 53,298.00$ which have little difference compare with the microcredit group.

\section{Results of the productivity analysis}

The results of the productivity analysis using the stochastic frontier production function (SFPF) estimation as obtained from Frontier 4.1 software were presented in the Table 3 . The maximum likelihood (ML) ratio test of the model was used to measure its overall fitness. The estimated values of sigma squared, gamma, log likelihood function LR test and mean efficiency gave further information on the efficiency of the explanatory variables on cassava production. The significance of the sigma-squared at 5\% level in the two groups indicated a good fit and correctness of the specified assumption of the distribution of the composite error term. The mean technical efficiencies (TEs) for the all samples, cassava farmers with access to microcredit and those without access to microcredit was found to be $96.25 \%, 96.38 \%, 95.56 \%$ respectively. This indicated that the efficiencies of the input used were very high and that the technical efficiencies of the groups could be increased by $3.75 \%, 3.62 \%$, and $4.44 \%$ respectively. Adjusting from the mean of all the groups, it was obvious that all the groups were close to the point of profit maximization but the microcredit users was a little closer to profit maximization hence; that group was more technically efficient than others. This result agreed with the findings of Ambai, (2013) who posited that access to microcredit among farmers could lead to increase efficiency. The coefficients for labour, farm size, fertilizer, were significant and positive for the all samples at 5\% level of significance. This result implied that a percentage increase in labour, farm size and fertilizer would increase the output by $68.97 \%, 287.69 \%$ and $35.68 \%$ respectively for all samples. The coefficients of membership in association was also significant but had negative relationship. Total cost had a positive significant relationship with the output at $10 \%$ level of significance. This implied that a percentage increase in total cost would increase the output level by $2.5 \%$ for all samples. For non-users of microcredit, the coefficients of farm size and fertilizer were positive and significant at 5\% level of significance and this implied that an increase in farm size and fertilizer would increase the output by $16.27 \%$, and $37 \%$ respectively. 
Table 3: Maximum- likelihood estimates of farmers that have access to microcredit, farmers without access microcredit and all the sampled farmers.

\begin{tabular}{|c|c|c|c|c|c|c|c|c|c|}
\hline \multirow{2}{*}{$\begin{array}{l}\text { Variables } \\
\text { Efficiency factors }\end{array}$} & \multicolumn{3}{|c|}{ All samples } & \multicolumn{3}{|c|}{ Farmers without access to microcredit } & \multicolumn{3}{|c|}{$\begin{array}{l}\text { Farmers with access to } \\
\text { microcredit }\end{array}$} \\
\hline & Coefficients & Standard error & t-value & Coefficients & $\begin{array}{l}\text { Standard } \\
\text { error }\end{array}$ & t-value & Coefficients & $\begin{array}{l}\text { Standard } \\
\text { error }\end{array}$ & T-value \\
\hline Constant term & $18167.760^{* *}$ & 16.0736 & 1130.2843 & $28133.9840 * *$ & 1.0187 & 27617.7030 & $17729.817^{* *}$ & 31.7172 & $558 . .9962$ \\
\hline Labour & $68.9715^{* *}$ & 083.7773 & 3.75299 & -10.0264 & 8.4827 & -1.1820 & $146.7873^{* *}$ & 21.7178 & 6.7588 \\
\hline Farm size & $287.6912 * *$ & 13.04712 & 22.0502 & $1690.2736^{* * *}$ & 1.1199 & 1509.3133 & -26.4418 & 82.7196 & -0.3197 \\
\hline Fertilizer & $35.6822 * *$ & 11.4498 & 3.1166 & $37.3082 * *$ & 15.4413 & 2.4161 & $16.03013 * *$ & 7.7749 & 2.0688 \\
\hline Members of association & $-82.6615^{* *}$ & 19.2786 & -4.2877 & $-1346.1190 * *$ & 1.0509 & -1280.9491 & $-2612.6403 * *$ & 60.4630 & -43.2106 \\
\hline Total cost & $0.02510 * * *$ & 0.0150 & 1.6922 & $\begin{array}{l}0.02028 \\
\text { Inefficiency factors }\end{array}$ & 0.0234 & 0.8677 & 0.0120 & 93.8816 & 1.2816 \\
\hline Constant term & -1.8810 & 7.7611 & -0.2426 & 0.00223 & 1.0003 & 0.0023 & 15.3709 & 17.7506 & 0.8659 \\
\hline Farming exp. & $138.3610^{* * *}$ & 82.3869 & 1.6794 & -2.7457 & 27.2101 & -0.1009 & 151.4898 & 164.3207 & 0.9219 \\
\hline Household size & -171.8787 & 295.4108 & 0.5818 & -14.8176 & 128.7806 & -0.1151 & -1057.7980 & 1216.6487 & -0.8694 \\
\hline Education & -483.0853 & 702.3951 & 0.6878 & $-0.2632 * *$ & 2.7902 & -9.4345 & -19822.9990 & 2279.9671 & -0.8694 \\
\hline Gender & 82.7657 & 338.9141 & 0.2442 & $0.1954^{* *}$ & 2.1522 & 9.0804 & 371.0005 & 426.7641 & 0.8693 \\
\hline Extension visit & 53.75635 & 201.6692 & 0.2666 & $\begin{array}{l}0.0922 * * \\
\text { Diagnostic statistics }\end{array}$ & 1.3512 & 6.8243 & 372.3289 & 428.2570 & 0.8694 \\
\hline Sigma-squared & $98516719 * *$ & 1.0001 & 985166698 & $112017510^{* *}$ & 1.3512 & 112017510 & $46492069.0000^{* *}$ & 1.0002 & $\begin{array}{l}46484448 . \\
0000\end{array}$ \\
\hline Variance ratio(gamma) & 0.00067 & 0.0008 & 0.8448 & 0.03292 & 0.14697 & 0.2240 & 0.1262 & 0.1313 & 0.9612 \\
\hline LR Test & 0.3 .1403 & & & 0.03454 & & & 0.9467 & & \\
\hline Log likely hood function & -1058.9931 & & & -554.8148 & & & -0.4906 & & \\
\hline Mean efficiency & 0.9625 & & & 0.9556 & & & 0.9638 & & \\
\hline
\end{tabular}

Source: field Survey, 2017 *** Significant at 10\% ** Significant at 5\%* Significant at 1\% 
The result of microcredit users showed that the coefficient of labour and fertilizer had a positive significance at $5 \%$. This implied that increase in this variable input would increase the output by $6.76 \%$ and $2.07 \%$ respectively. This result confirmed the findings of Atagher et al. (2014) which reported that increase in input used could affect the level of output among cassava farmers. For the inefficiency variables, coefficients of farming experience had a positive relationship with the level of efficiency and significant at $10 \%$ confidence interval for the all samples. The implication was that the more experience the farmer had on the cassava farming, the more efficient the would become in his allocation available resources. The coefficients of education had a negative relationship with farmers' level of efficiency and significant at 5\% level of confidence interval for farmers without access to microcredit. The coefficients of gender and extension visits had a positive significance at $5 \%$ level of significance. These results confirmed the findings of Yuguda et al. (2013) and Owoeye et al. (2018) on the socioeconomic factors influencing productivity and efficiency of cassava farmers in Nigeria.

\section{CONCLUSION}

This study concluded that cassava production in the study area was dominated by male farmers with relatively small farm sizes. The cassava farmers who had access to microcredit were more efficient and were able to make more investment into their farm business. As a result, they were able to make more profit compared to their counterparts which had no access to microcredit. The result of budgetary analysis indicated higher variable cost for farmers with access to microcredit which translated to the use of more of the improved technologies like fertilizer and other inputs. Generally, findings from this study showed that cassava production was a profitable enterprise in the study area. It was recommended that cassava farmers in the study area should be encouraged with adequate access to microcredit in order to improve their productivity and profit level.

\section{REFERENCE}

SAbdulahi A. (2003). Employment creation and opportunities in the agro-allied sub-sector; the case of cassava production. The Bullion Publication of CBN 27 (4), 1-10.

Ambai O. I. (2013). Microcredit and technical efficiency of rural farm households in Egba Division of Ogun State, Nigeria. Journal of Agriculture and Sustainability, 3 (2), 196 211.
Ashaolu O.F. Mamioh S. Philip B.B and Tijani I.A. (2011). Microcredit effect on agricultural productions: A comparative analysis of rural farmers in Ogun State, Nigeria. International Journal of Applied Agricultural Research. 7 (1), 20-31.

Atagher M.M. and Okorji E.C. (2014).Factors that enhance or reduce productivity among cassava women farmers in Benue State, Nigeria. Journal of Agriculture and Veterinary Science, 7 (5), 07-12.

.Balogun O.L. Yusuf S.A. Omonona B.T. and Okoruwa, V.O. (2011). Social capital and microcredit effects on poverty among rural households in Southwest States, Nigeria. ARPN Journal of Agricultural and Biological Science, 6 (3), 5-10.

Forson J. (1999). Factors influencing adoption of land-enhancing technology in the Sahel: Lessons from a case study in Niger. Journal of Agricultural Economics, 20, 231-239.

Miguel E. and Kremer M. (2007). The illusion of sustainability'. Quarterly Journal of Economics, 122, 1007-1065.

Nwaru J.C. (2011). Determinants of informal credit demand and supply among food crop farmers in Akwa Ibom State, Nigeria. Journal of Rural and Community Development, 6 (1), 129-139.

Ndubueze-Ogaraku M.E. and Ekine D.I (2014). Profitability of cassava production in the floodplain areas of rivers state, Nigeria. Nigeria journal of Agriculture, food and environment, 10 (2), 79-86.

Nigeria National Report, (2006). Rural reform and development in Nigeria. A report presented at International Conference on Agrarian Reform and Rural Development, Porto Alegre.

Nweke F. (2004). New challenges in the cassava transformation in Nigeria and Ghana Environment and Production Technology Division International Food Policy Research Institute $2033 \mathrm{~K}$ Street, N Washington DC 20006 USA www.Ifpri.org June 2004.

Odoemenem I.U. and Obinne C.P.O. (2010). Assessing the factors influencing the utilization of improved cereal crop production technologies by small scale farmers in Nigeria. Indian Journal of Science and Technology, $\mathbf{3}$ (1), 180-183.

Ojeniyi E.T. (2001). Processing and economics of production of lesser known cassava food products in South-Western Nigeria. In: Akoroda M. O. and Ngeve J.M. (Eds). Root crops in the 21 st century. Proceeding of the International Society For Tropical Root Crops -Africa Branch (ISTRC-AB) Cotonou, Benin.

Okoye B.C. Abass A. Bachwenkizi B.,AsumughaG.,Alenkhe B.,Ranaivoson R. and Baidu-Forson J. (1999). Factors influencing adoption of land-enhancing technology in the Sahel: Lessons from a case study in Niger. Journal of Agricultural Economics, 20, 231-239.

Owoeye R.S. and Toluwase S.O.W. (2018). Factors influencing resource use efficiency differentials of farm size among cassava farmers in Ekiti State, Nigeria. Asian Journal 
of Advances in Agricultural Research, 5 (2), 17.

Rahji M. and Fakayode S.A. (2009).A multinomial logit analysis of agricultural credit rationing by commercial banks in Nigeria, Int. Res. J. Fin. Econ., 24: 91.

Salvador E.M. Steenkamp V. and McCrindle C.M.E. (2014). Production, consumption and nutritional value of cassava (Manihotesculenta,Crantz) in Mozambique: An overview. Journal of agricultural Biotechnology and sustainable development, 6 (3), 29-38.

Simonyan J.B. Umoren B.D. and Okoye B.C. (2011). Gender differentials in technical efficiency among maize farmers in EssienUdim local government area, Nigeria.International Journal of Economics and Management Sciences, 1, 17-23.

Taiwo J.N. (2012). The Impact of microfinance on expenditure and poverty alleviation in southwestern Nigeria. an unpublished Ph.D thesis Department of Banking and Finance, Covenant University, Otta, Nigeria.
Udensi E.,Tarawali U.,Ebere G.,FavourU., Godwin A.,Chuma E.,Benjamen C., Okoye C. O.,Ilona P.,OkechukwuR. andDixon, A. (2011).Adoption of selected improved cassava varieties among smallholder farmers in SouthEastern Nigeria.Journal of Food, Agriculture and Environment9 1 (3), $29-335$.

Yakasai M.T. (2010). Economic contribution of cassava production (a case study of Kuje Area council, Federal capital territory, Abuja, Nigeria. Bayero. Journal of Pure and Applied Sciences, 3 (1), 215-219.

Yuguda R.M. Girei A.A. Dire B. and Salihu M. (2013). Socio -economic factors and constraints influencing productivity among cassava farmers in Taraba State, Nigeria. International Journal of Advances in Agricultural Science and Technology, 1 (1), 115.

Zahra T. and Gulcan O. (2016) Microcredit Programs, Poverty and Vulnerability in Rural Iran. Selected paper prepared for presentation at the Southern Agricultural Economics Association's 2016 Annual Meeting, San Antonio, Texas, February, 6/9/2016. 